\title{
Effects of Coralliophila violacea on tissue loss in the scleractinian corals Porites spp. depend on host response
}

\author{
L. J. Raymundo ${ }^{1, *}$, T. M. Work ${ }^{2}$, R. L. Miller ${ }^{3}$, P. L. Lozada-Misa ${ }^{4}$ \\ ${ }^{1}$ University of Guam Marine Laboratory, Mangilao, Guam 96923, USA \\ ${ }^{2}$ USGS National Wildlife Health Center, Honolulu Field Station, Honolulu, Hawaii 96850, USA \\ ${ }^{3}$ Guam Coral Reef Monitoring Program, Bureau of Statistics and Plans, Guam 96923, USA \\ ${ }^{4}$ National Oceanic and Atmospheric Administration, Honolulu, Hawaii 96818, USA
}

\begin{abstract}
We investigated interactions between the corallivorous gastropod Coralliophila violacea and its preferred hosts Porites spp. Our objectives were to experimentally determine whether tissue loss could progress in Porites during or after Coralliophila predation on corals with and without tissue loss and to histologically document snail predation. In $64 \%$ of feeding scars, tissue regenerated within 3 wk, leaving no trace of predation. However, in roughly $28 \%$ of scars, lesions progressed to subacute tissue loss resembling white syndrome. In feeding experiments, scars from snails previously fed diseased tissue developed progressive tissue loss twice as frequently as scars from snails previously fed healthy tissue. Scars from previously healthy-fed snails were 3 times as likely to heal as those from previously diseased-fed snails. Histology revealed marked differences in host responses to snails; $P$. cylindrica manifested a robust inflammatory response with fewer secondary colonizing organisms such as algae, sponges, and helminths, whereas $P$. rus showed no evident inflammation and more secondary colonization. We conclude that lesion progression associated with Coralliophila may be associated with secondary colonization of coral tissues damaged by predator-induced trauma and necrosis. Importantly, variation at the cellular level should be considered when explaining interspecific differences in host responses in corals impacted by phenomena such as predation.
\end{abstract}

KEY WORDS: Coralliophila $\cdot$ Coral disease $\cdot$ White syndrome $\cdot$ Porites $\cdot$ Guam

\section{INTRODUCTION}

It is thought that organisms that prey on or compete with corals can potentially transmit infectious agents resulting in lesions via physical trauma, deposition of fecal waste, or physical contact. If such organisms carry the infectious agent, they are considered vectors, and an increase in the abundance of a vector may then result in increased disease transmission. In corals, conclusive evidence for the existence of vectors is rare; the fireworm Hermodice carunculata is the only known case of a corallivore potentially transmitting a bacterial agent to its host coral (Sussman et

\footnotetext{
*Corresponding author: ljraymundo@gmail.com
}

al. 2003). However, several recent studies have suggested that organisms that interact with coral may be implicated in certain infections, although the mechanisms for this effect are often unclear. For instance, physical contact between corals and the macroalga Halimeda opuntia facilitated white plague (Nugues et al. 2004). Crown-of-thorns starfish Acanthaster planci have been implicated in brown band disease (Nugues \& Bak 2009), and corallivorous snails may transmit a pathogen associated with white syndrome (Antonius \& Riegl 1997, Williams \& Miller 2005). Raymundo et al. (2009) revealed a significant positive correlation between the abundance of obligate coral-

() The authors 2016. Open Access under Creative Commons by Attribution Licence. Use, distribution and reproduction are unrestricted. Authors and original publication must be credited. 
livorous butterflyfish and coral disease prevalence; in reefs protected from fishing, corallivorous chaetodontids were less abundant, as were coral diseases.

Conversely, by debriding damaged tissues, predators can also reduce lesion impacts in corals. For instance, certain corallivorous fish prefer diseased or damaged coral tissue (McIlwain \& Jones 1997, Aeby 2002), and animals feeding on diseased tissue can slow the progression of lesions (Cole et al. 2009). Crabs can also slow progression of white syndrome in Acropora (Pollock et al. 2013).

Implicit in the scenario of corallivores as vectors is a tacit assumption that these organisms are transmitting, exacerbating, or alleviating infectious diseases in corals. However, many of the diseases with which these competitors or predators are associated have no well-defined causes, particularly those involving tissue loss (Work \& Meteyer 2014). Concluding that an interacting organism is a vector requires not only the presence of the suspect infectious agent in the organism, but also evidence that this agent is associated with cell death in the coral. Currently, the main evidence used to incriminate predators as vectors of coral diseases is gross evidence of lesion progression in corals in the presence of predators (Work \& Meteyer 2014). However, an equally plausible explanation for this observation is that, by damaging tissues, coral predators create portals of entry for secondary colonizers that either exacerbate lesions or prevent healing. In either case, understanding the nature of interactions between host corals and corallivores can elucidate patterns of disease on coral reefs, particularly in light of the fact that at least some of these organisms, such as crown-of-thorns starfish (De'ath et al. 2012) or Drupella (Moyer et al. 1982), can reach outbreak population densities.

Coralliophila violacea is a muricid corallivorous snail that prefers poritid corals in the Indo-Pacific and Red Sea. The unique feeding mode of this snail, referred to as 'prudent feeding,' involves insertion of a proboscis into the coral polyp's coelenteron, allowing the snail to remain stationary for extended periods while consuming coral tissues (Ward 1965, Brawley \& Adey 1982). Snails remain firmly attached for months, killing the underlying tissue and creating a distinct scar surrounded by accreted coral skeleton. Snails are often clustered on massive corals but singly on branching corals (Chen et al. 2004), and this creates variably sized zones of tissue injury that stimulate host tissue regeneration. In Porites, Oren et al. (1998) documented translocation of carbon into these injury zones from surrounding tissue to promote healing, with the net result of creating a continual supply of food for C. violacea.

In Guam, acute to subacute tissue loss (white syndrome) in Porites is highly prevalent (Myers \& Raymundo 2009), and our surveys of coral diseases occasionally noted progressive tissue loss beyond Coralliophila feeding scars on Porites spp. Further, some tissue-loss lesions sometimes displayed signs of a snail scar within the lesion. To shed light on the role of this snail in Porites tissue loss, we set out to (1) experimentally determine whether tissue loss could progress in Porites in the presence of Coralliophila or in association with a recent feeding scar; and (2) document histology of snail predation to better understand potential underlying mechanisms of tissue damage and host response.

\section{MATERIALS AND METHODS}

All studies were carried out between March and December 2011 in the University of Guam Marine Lab wet lab (tank studies) and at Luminao Reef, Guam (field observations). Corals for histology were collected from Luminao and Gabgab reefs, fixed, and sent to the National Wildlife Center Honolulu Field Station, Hawaii, USA, for processing and analysis.

To examine the fate of scars in situ, 25 colonies of the branching coral Porites cylindrica hosting a snail, but with no gross clinical signs of tissue loss, were tagged in Luminao reef, Guam, and the snail was removed. The scar was photographed and condition of the tissue margin noted. Scars were photographed weekly for $3 \mathrm{wk}$ after snail removal and scored as (1) healing: tissue deposition over dead skeleton along the scar margin; (2) static: an eroded scar margin with no tissue deposition; or (3) progressing: continued tissue loss beyond the original scar border. To test for the ability of snails to transmit tissue loss between colonies, 40 plates of $P$. rus, ranging from 4 to $8 \mathrm{~cm}$ in diameter, were collected from Gabgab reef, Guam. Ten plates had acute to subacute tissue loss, and 30 plates were clinically healthy on collection. Twenty adult snails were collected from the same reef. The 10 plates containing lesions ('diseased plates') and 10 apparently healthy plates (corals with no gross evidence of lesions) were placed in individual 21 aerated aquaria and randomly arranged in water baths at the University of Guam Marine Lab. Snails were starved for $24 \mathrm{~h}$, then randomly distributed among the 20 fragments. Snails assigned to diseased fragments were placed on the margin of an active lesion, while snails assigned to 
healthy fragments were haphazardly placed on healthy tissue. Snails were allowed to feed for $1 \mathrm{wk}$, after which they were removed and immediately placed on the remaining 20 healthy fragments, randomized in additional aquaria. We tracked which fragments were fed upon by snails that had previously fed on tissue-loss lesions vs. those previously fed apparently healthy fragments. Snails were allowed to feed for an additional week and then
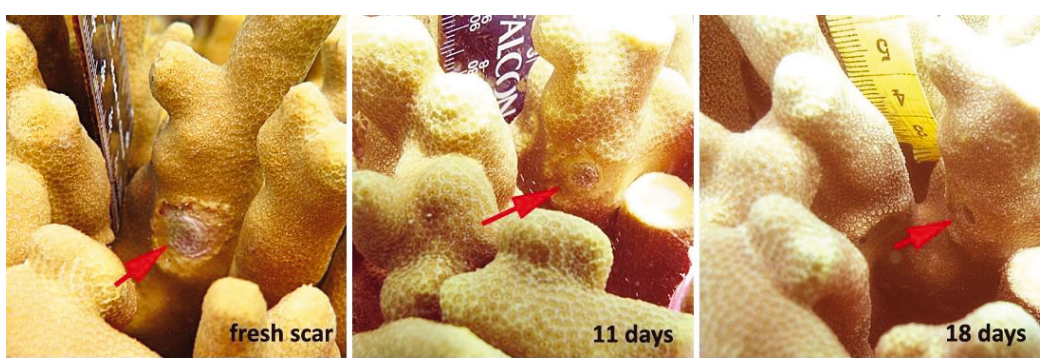

Fig. 1. Time series photographs of a colony of Porites cylindrica with a single healing Coralliophila violacea scar (red arrow). Note the skeletal accretion around the new scar and the tissue deposition that resulted in rapid healing removed. Resultant scars were monitored for 2 wk and scored as healing, static, or progressing, as described above. Chisquared tests were used to test whether the fate of feeding scars differed between treatments (diseasedfed vs. healthy-fed), and ANOVAs were used to examine differences in the rate of lesion progression or healing. Data were transformed, where necessary, to meet assumptions of normality.

Histology of snail predation scars on coral tissue was examined on 11 and 13 colonies each of P. cylindrica and $P$. rus, collected from Luminao reef ( $P$. cylindrica) and Gabgab reef ( $P$. rus) in August 2010 and immediately fixed in Z-fix ${ }^{\circledR}$ concentrate diluted 1:5 in seawater as per the manufacturer's recommendations. Gross lesions were classified as recent ( $\leq 10$ d old; no skeletal accretion and partial tissue loss) or old (>10 d; skeletal accretion apparent and complete tissue loss). Tissues were processed for histology and interpretation as described by Work et al. (2012). Briefly, tissues were decalcified, embedded in paraffin, sectioned at $5 \mu \mathrm{m}$, and stained with hematoxylin and eosin, stains adequate to identify cyanobacteria (Sato et al. 2010) and Gram-positive or Gram-negative microcolonies of bacteria (Work \& Aeby 2014). On microscopy, changes were classified as 'host response' or 'organisms associated with host response.' Host responses included necrosis, deposition of hyaline or basophilic membranes, fragmentation, cleft formation, hypertrophy, atrophy, or infiltration of mesogleal cells (inflammation). Organisms were categorized as helminths, fungi, algae, or ciliates.

\section{RESULTS}

Of the 25 snail scars monitored in intact colonies in situ, the majority (64\%) healed within $3 \mathrm{wk}$ (Fig. 1). Healing lesions had intact margins with healthy tissue overgrowing bare skeleton. Two scars remained

static, with a margin of skeletal accretion surrounding the scar with no evident regeneration of coral tissues after snail removal. Seven scars (28\%) progressed, showing gross signs of tissue loss similar to white syndrome.

In the laboratory feeding experiment, several plates developed more than 1 feeding scar due to snail movement (Fig. 2). We tracked the fate of each scar formed and later pooled the data for statistical tests, after tests for an effect of source plate on lesion fate revealed no significant differences. The majority of feeding scars on corals exposed to snails previously fed diseased tissue exhibited progressing lesions after snails were removed, while the majority of scars formed by snails previously fed healthy tissue healed (Table $1 ; \chi^{2}=4.891 ; \mathrm{p}=0.0270$ ). Interestingly, the rate at which scars either healed or formed progressing lesions was not significantly different between treatments (roughly $0.25 \mathrm{~cm} \mathrm{~d}^{-1}$; ANOVA $\left.F_{1,24}=0.8168 ; \mathrm{p}=0.385\right)$, although the apparent difference in tissue loss rate in plates with healthy-fed snails (Table 1) was due to a single lesion that progressed very rapidly. When that lesion was removed from the analysis, the rate at which lesions progressed in healthy-fed scars was reduced to $0.16 \pm$ 0.09 (SD) $\mathrm{cm} \mathrm{d}^{-1}$, but this difference was still not significant (ANOVA $F_{1,24}=0.013 ; \mathrm{p}=0.908$ ).

A number of host responses to snail predation were observed histologically (Table 2). The most common host response for both $P$. cylindrica and $P$. rus was deposition of basophilic membranes either on the surface (Fig. 3A) or within (Fig. 4A) tissues, necrosis with hyaline membrane formation (Fig. 3A-D), and ablation of the surface body wall (Figs. 3A \& 4A). For P. cylindrica, surface body wall ablation, hypertrophied calicodermis, and mucus cell hypertrophy were seen exclusively in new snail lesions (Fig. 3), whereas cleft formation between surface and basal body wall was present only in 

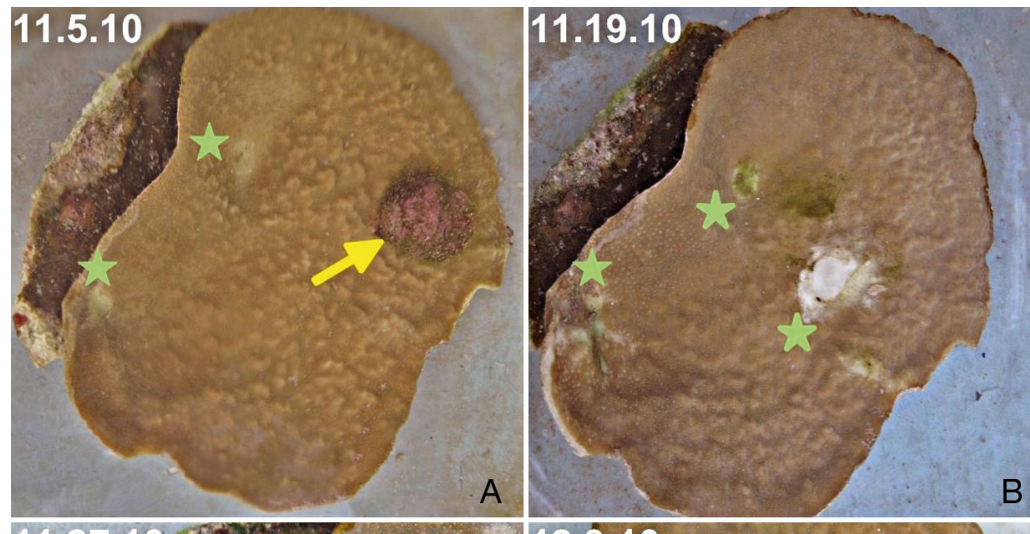

(Figs. 3A-D). Algae (Figs. 3E,F \& Fig. 4B) were the dominant organisms seen on microscopy and were present only in old lesions for P. cylindrica, whereas algae were seen in both new and old lesions for $P$. rus (Table 2). Endolithic sponges, fungal hyphae, and helminth worms constituted other organisms associated with lesions.

\section{DISCUSSION}
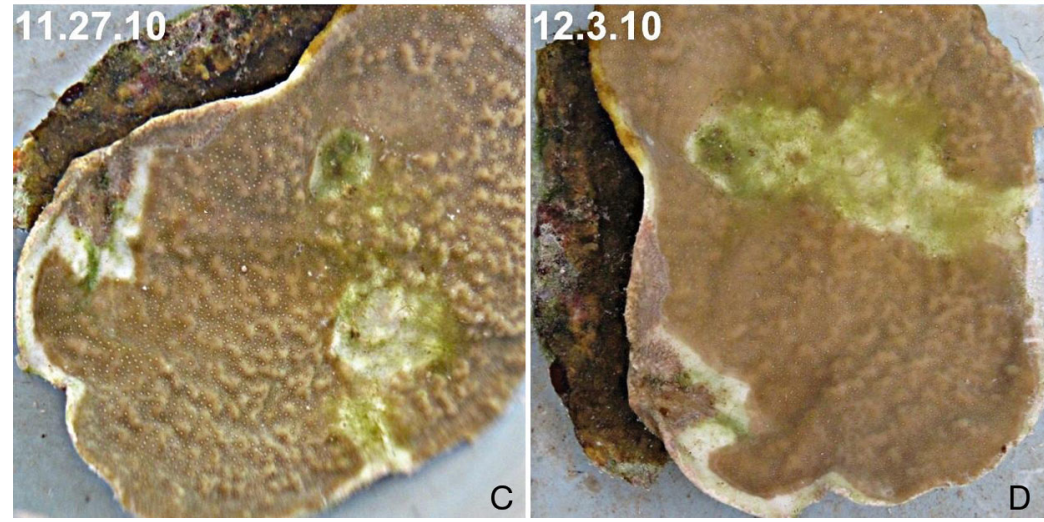

Fig. 2. Time series photographs of progressive tissue loss resembling white syndrome in Porites rus, originating from 3 feeding scars (green stars in panel A,B, with the snail indicated by the yellow arrow in A creating a third scar). Tissue continued to slough after the snail was removed on November 5, 2010 (panels B-D). Areas of tissue loss coalesced, forming a large lesion, with additional tissue loss initiating along the left border of the fragment around another feeding scar (panels $\mathrm{C}$ and D). Dates are given as mm.dd.yy

Table 1. Fate of feeding scars formed on healthy Porites rus plates ( $\mathrm{n}=10$ per treatment; several plates contained $>1$ scar) partitioned by feeding treatment. Diseased-fed: Coralliophila violacea snails previously fed diseased coral tissue; healthy-fed: $C$. violacea snails previously fed healthy coral tissue. Census taken $7 \mathrm{~d}$ after removal of snails

\begin{tabular}{|c|c|c|}
\hline Metric & Diseased-fed & Healthy-fed \\
\hline Total feeding scars & 13 & 14 \\
\hline Number of lesions progressing (\%) & $9(69)$ & $4(28)$ \\
\hline Number of feeding scars healing (\%) & $3(23)$ & $9(65)$ \\
\hline No lesions formed (\%) & $1(8)$ & $1(7)$ \\
\hline Lesion progression rate $\left(\mathrm{cm} \mathrm{d}^{-1} \pm \mathrm{SD}\right)$ & $0.24 \pm 0.3$ & $0.47 \pm 0.62$ \\
\hline Feeding scar healing rate $\left(\mathrm{cm} \mathrm{d}^{-1} \pm \mathrm{SD}\right)$ & $0.27 \pm 0.3$ & $0.21 \pm 0.16$ \\
\hline
\end{tabular}

old lesions (Fig. 4). For P. rus, wound repair was seen only in new lesions, whereas necrosis and cleft formation were seen only in old lesions. Mucus and calicodermal cell hypertrophy and inflammation, characterized by prominent infiltrates of melaninlike granular cells, were seen only in $P$. cylindrica known. Recent discussions of the role of endoliths on calcium carbonate-secreting organisms cite both positive and negative effects on the host (Tribollet 2008). Fungi penetrate and dissolve coral skeleton and attack both endolithic algae and coral polyps (Bentis et al. 2000). Ostreobium spp., endolithic algae in many normal corals, can colonize

Evidence that snails were transmitting a pathogen leading to tissue loss in Porites was equivocal, although our results clearly showed that snail feeding was associated with progressive tissue loss in snails previously exposed to acute tissue loss lesions. Histology failed to detect bacterial or viral inclusions associated with either old or new snail-induced lesions, although the use of light microscopy cannot preclude the presence of viruses that were not numerous enough to form inclusions. The lack of concordance between the assumption that tissue loss (white syndrome, WS) is caused by bacteria and absence of histological evidence of the presence of bacteria associated with cell death in WS-affected coral has been pointed out elsewhere (Ainsworth et al. 2007, Work et al. 2012), although it has also been suggested that there may be more than 1 causal agent associated with this suite of disease signs (Work et al. 2012, Bourne et al. 2015). We propose that secondary colonizers, primarily algae, may be responsible for lesion progression after snail removal, but the mechanism by which they might cause progressive tissue loss remains un- 
Table 2. Percent of Porites cylindrica and P. rus manifesting particular histological changes partitioned by whether Coralliophila violacea snail-induced lesions were new ( $\leq 1 \mathrm{wk})$ or old $(>1 \mathrm{wk})$, and host response or organisms associated with the lesions

\begin{tabular}{|c|c|c|c|c|c|c|c|c|c|c|}
\hline \multirow[t]{2}{*}{ Parameter } & \multicolumn{4}{|c|}{ — Porites cylindrica $(\mathrm{n}=11)$} & \multicolumn{4}{|c|}{ Porites rus $(\mathrm{n}=13)$} & \multicolumn{2}{|c|}{ All colonies } \\
\hline & New & Old & Total & $\%$ & New & Old & Total & $\%$ & $\mathrm{n}$ & $\%$ \\
\hline \multicolumn{11}{|l|}{ Host response } \\
\hline Basophilic membrane & 4 & 2 & 6 & 55 & 2 & 4 & 6 & 46 & 12 & 50 \\
\hline Necrosis & 2 & 3 & 5 & 45 & 0 & 6 & 6 & 46 & 11 & 46 \\
\hline Hyaline membrane & 5 & 2 & 7 & 64 & 1 & 3 & 4 & 31 & 11 & 46 \\
\hline Fragmentation & 4 & 0 & 4 & 36 & 3 & 2 & 5 & 38 & 9 & 38 \\
\hline Cleft formation & 0 & 2 & 2 & 18 & 0 & 4 & 4 & 31 & 6 & 25 \\
\hline Hypertrophy calicodermis & 2 & 0 & 2 & 18 & 0 & 0 & 0 & 0 & 2 & 8 \\
\hline Mucus cell hypertrophy & 3 & 0 & 3 & 27 & 0 & 0 & 0 & 0 & 3 & 13 \\
\hline Inflammation & 2 & 1 & 3 & 27 & 0 & 0 & 0 & 0 & 3 & 13 \\
\hline Wound repair & 0 & 0 & 0 & 0 & 1 & 0 & 1 & 8 & 1 & 4 \\
\hline Atrophy & 0 & 0 & 0 & 0 & 0 & 1 & 1 & 8 & 1 & 4 \\
\hline \multicolumn{11}{|l|}{ Organisms } \\
\hline Algae & 0 & 1 & 1 & 9 & 2 & 0 & 2 & 15 & 3 & 13 \\
\hline Fungi & 0 & 1 & 1 & 9 & 1 & 1 & 2 & 15 & 3 & 13 \\
\hline Sponges & 0 & 1 & 1 & 9 & 0 & 1 & 1 & 8 & 2 & 8 \\
\hline Helminths & 0 & 2 & 2 & 18 & 0 & 0 & 0 & 0 & 2 & 8 \\
\hline
\end{tabular}

host skeleton following tissue loss, penetrating live coral tissue, which could influence regeneration (Fine et al. 2006). The absence of bacteria associated with cell death in early lesions in $P$. cylindrica and $P$. rus argues against snails acting as vectors of bacterial pathogens, as these would presumably be visible in early lesions if they were transmitted by snails. However, the more common presence of fungi and algae in both early and late $P$. rus lesions is intriguing and suggests more rapid colonization of this species by secondary organisms.

Work et al. (2012) and Bourne et al. (2015) discussed the evidence for multiple causative agents for WS, which may constitute a suite of diseases. Our results suggest that different processes may be at work in the 2 coral host species we examined, with similar gross signs of disease associated with a single corallivore. Predation scars can serve as entry wounds that become invaded after the snail moves. At least 2 other coral diseases, viz. skeletal eroding band (Page \& Willis 2008) and brown band disease (Nicolet et al. 2013), can be initiated by damage to the coral surface. Additionally, our evidence indicates that snail feeding facilitates colonization of coral by secondary organisms. Clearly, snails can cause tissue necrosis and, depending on the host's ability to respond, subsequent progressive tissue loss associated with secondary colonizers.

Our feeding experiments revealed that rates of tissue loss and healing were not significantly different, either between or within feeding treatments. Tissue loss rates were highly variable, and our small replicate size may account for a failure to reveal a possible treatment effect. Healing rate is a process dictated by how rapidly new tissue can be produced to resheet bare skeleton. Thus, this process would not be expected to differ between treatments if disease signs were absent within the lesion. Lozada-Misa et al. (2015) reported in situ tissue loss lesion healing rates of $0.15 \pm 0.3(\mathrm{SD}) \mathrm{cm} \mathrm{d}^{-1}$ in P. cylindrica and $0.015 \pm$ $0.002 \mathrm{~cm} \mathrm{~d}^{-1}$ for massive Porites. Thus, the rates we observed for $P$. rus, a close relative, are comparable. Furthermore, the artificial environment of the aquaria may influence both tissue loss and healing processes.

Microscopy provided a potential explanation for the behavior of gross lesions induced by Coralliophila. Deposition of basophilic membrane within coral tissues has not been seen previously in Porites examined histologically in the Pacific (Williams et al. 2011, Sudek et al. 2012, Work et al. 2014, 2016), and this change might serve as a useful histological marker of snail predation in corals. The necrosis seen would fit with the snail's strategy of secreting proteolytic enzymes to aid in consumption and digestion of coral tissues (Ward 1965). However, we saw differences in host response to predation. Like P. compressa (Sudek et al. 2012), P. cylindrica manifested a prominent inflammatory response comprising hypertrophied calicodermis and infiltrates of melanin-like granule cells. Other congeners, such as massive Porites, can mount robust inflammatory responses, 

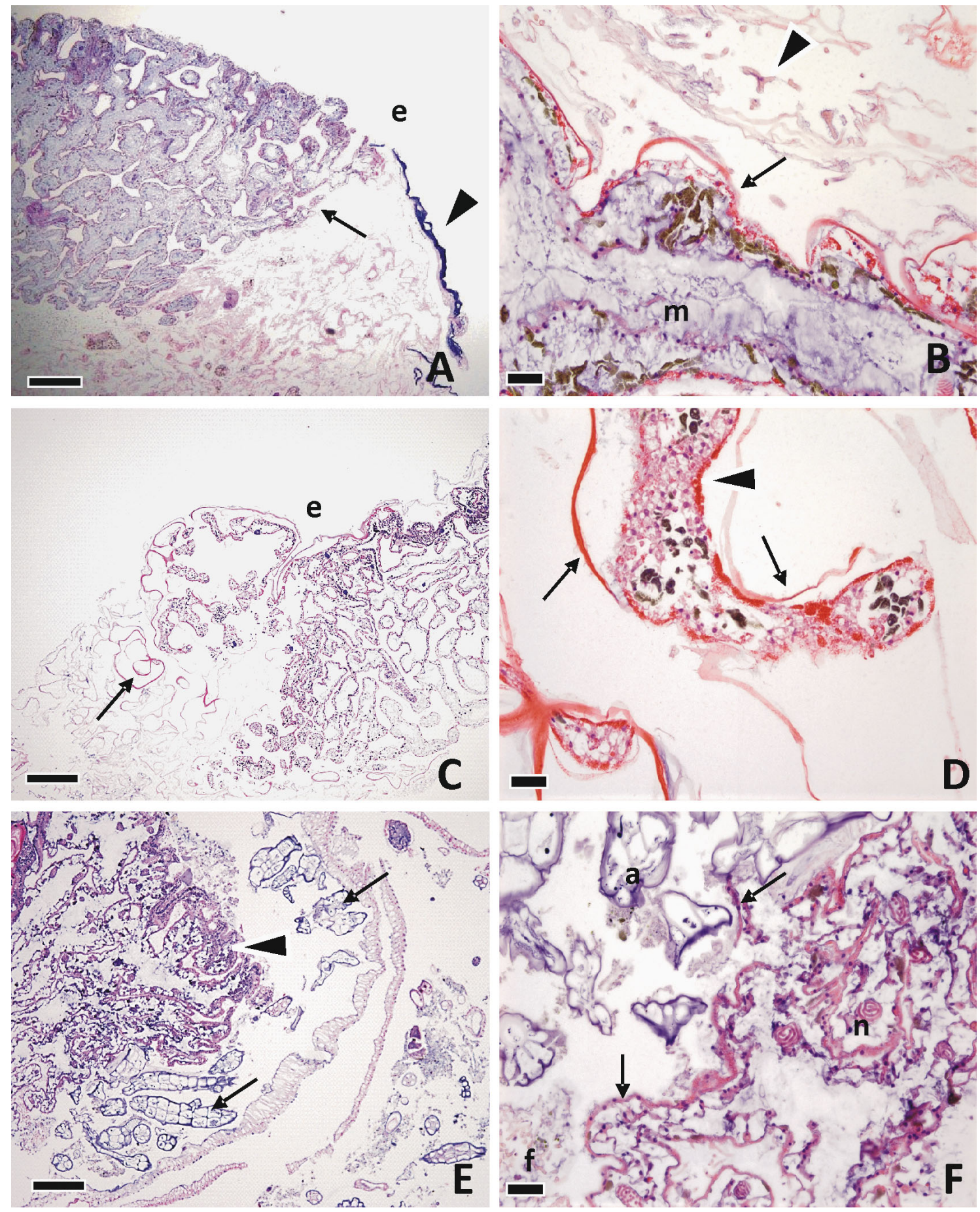

Fig. 3. Hematoxylin and eosin stained tissue sections of new ( $\leq 10 \mathrm{~d})$ Coralliophila violacea snail-induced lesions in (A-D) Porites cylindrica and (E,F) P. rus. with paired low $(\mathrm{A}, \mathrm{C}, \mathrm{E})$ and high $(\mathrm{B}, \mathrm{D}, \mathrm{F})$ magnification photomicrographs; e: epidermis, $\mathrm{m}$ : mucus, a: algae, f: fungi, n: nematocyst. (A) Diffuse full thickness necrosis of surface and basal body wall; arrow points to border of intact (upper left) and necrotic (lower right) tissues with deposition of basophilic membrane (arrowhead); scale bar = $500 \mu \mathrm{m}$. (B) Close up of Panel A at arrow. Note copious mucus within basal body wall and deposition of hyaline membranes (arrow) with occasional fungal hyphae within necrotic debris (arrowhead); scale bar $=20 \mu \mathrm{m}$. (C) Necrosis of surface and basal body wall with deposition of hyaline membranes (arrow); scale bar $=500 \mu \mathrm{m}$. (D) Close up of Panel C at border of necrotic area; note basal body wall becoming progressively attenuated with hypertrophied calicodermis (arrowhead) and deposition of hyaline membranes (arrows); scale bar $=20 \mu \mathrm{m}$. (E) Invasion of coral tissues by algae (arrows) associated with necrosis (arrowhead); scale bar $=200 \mu \mathrm{m}$. (F) Close up of Panel E at arrowhead; note algae and fungi apposed to clumps of gastrodermal cells manifesting pyknosis and hypereosinophilia (arrows); scale bar $=20 \mu \mathrm{m}$ 


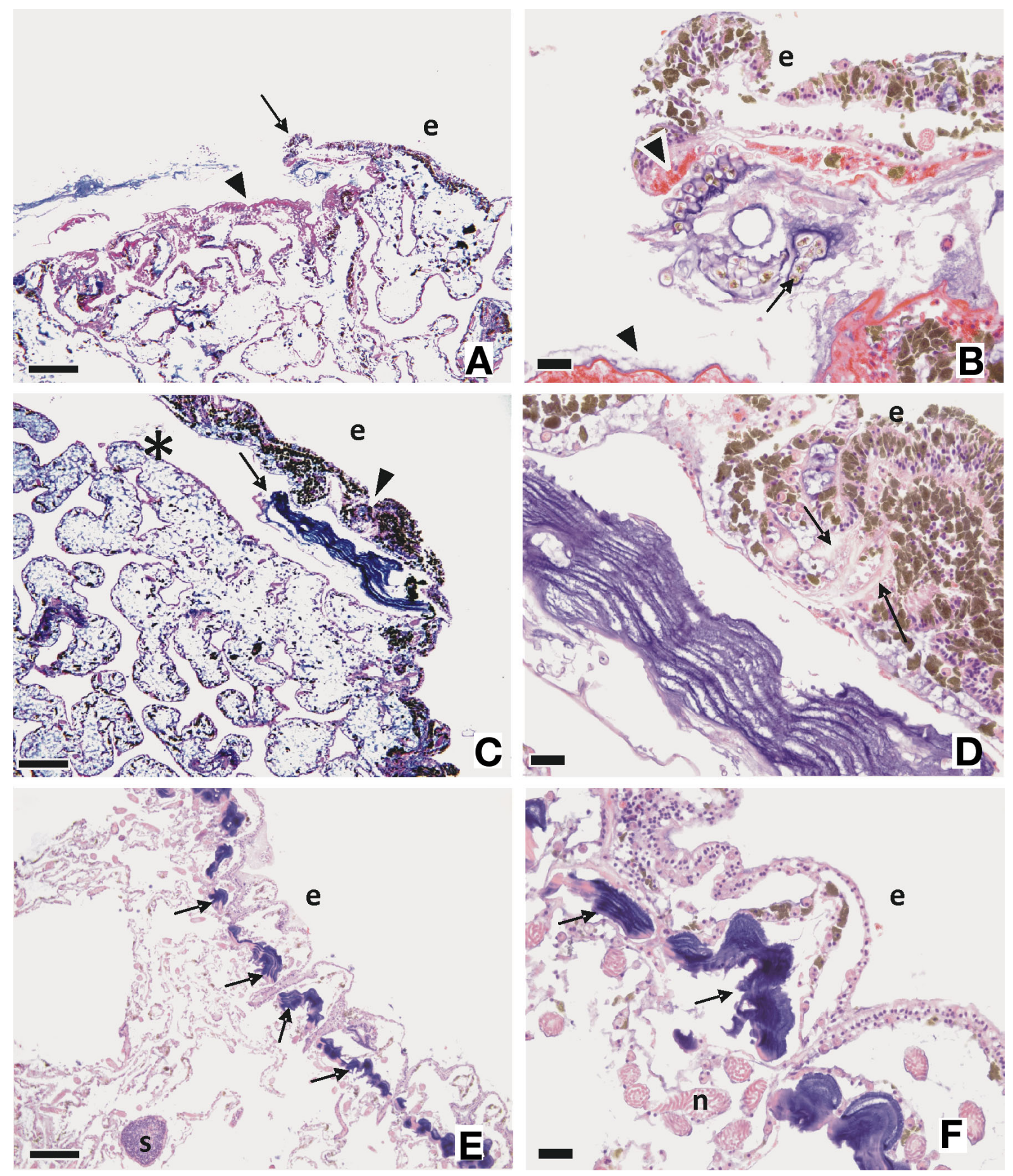

Fig. 4. Hematoxylin and eosin-stained tissue sections of old ( $>10 \mathrm{~d})$ Coralliophila violacea snail-induced lesions in (A-D) Porites cylindrica and $(\mathrm{E}, \mathrm{F}) P$. rus with paired low $(\mathrm{A}, \mathrm{C}, \mathrm{E})$ and high $(\mathrm{B}, \mathrm{D}, \mathrm{F})$ magnifications; e: epidermis, n: nematocyst, s: spermary. (A) Ablation of surface body wall (arrow) with hypertrophy of calicodermis (arrowhead); scale bar $=500 \mu \mathrm{m}$. (B) Close up of Panel $A_{i}$ note clumps of plant material with cell walls (arrow) surrounded by basophilic wispy material, hypertrophied and granular calicodermis (arrowhead), and epidermis infiltrated with melanin-like granule cells; scale bar $=20 \mu \mathrm{m}$. $(\mathrm{C}) \mathrm{Cleft}$ formation (asterisk) with deposition of basophilic membrane (arrow) and lifting of surface body wall that is infiltrated with melanin-like granule cells (arrowhead); scale bar $=200 \mu \mathrm{m}$. (D) Close up of Panel $C_{i}$ note basophilic laminar membrane overlaid by surface body wall with portions of gastrodermis separated by mesoglea (arrows) and infiltrates of melanin-like granule cells; scale bar $=20 \mu \mathrm{m}$. (E) Deposition of basophilic-laminated membrane below the surface body wall (arrows); scale bar $=$ $500 \mu \mathrm{m}$. (F) Higher magnification view of Panel E; note that basophilic membranes (arrows) appear to be deposited into gastrodermis; scale bar $=20 \mu \mathrm{m}$ 
particularly of melanin-like granule-containing cells, similar to those seen in this study (Palmer et al. 2008). Calicodermal hypertrophy would explain skeletal accretion at the edges of snail lesions; evidently, deposition of aragonite by calicodermal cells forms part of the host response repertoire in P. cylindrica (Allemand et al. 2011). Given their close association with hypertrophied calicodermis, we suspect that hyaline membranes were acid-rich proteins of the skeletal organic matrix (Mass et al. 2014). In contrast, P. rus displayed a minimal inflammatory response. Colonizing organisms such as algae and fungi were present mainly in older lesions for P. cylindrica, whereas they were more common in early and late lesions in $P$. rus. This may be linked with the superior inflammatory response of $P$. cylindrica that would presumably dissuade colonization by opportunistic organisms for longer than P. rus.

In summary, our study illustrates the power of combining gross observations with microscopy to explain biological phenomena in corals and yield insights into disease processes. In this case, snails caused significant damage to corals by opening portals of entry for secondary colonizers. The degree of damage to the colony may depend, in part, on the robustness of the host inflammatory response. Whilst the snails cannot be considered vectors of infectious agents, it is possible that they could move algae and fungi between corals, and histology of snails associated with corals may shed light on this question.

Acknowledgements. This work was supported by a grant from the NOAA Coral Reef Conservation Program to L.J.R. and G. Aeby. A. Miller, T. Reynolds, and R. Diaz assisted in laboratory experiments. Discussions with G. Aeby guided the experimental set up. Mention of products or trade names does not imply endorsement by the US Government. We thank the anonymous reviewers for their comments, which greatly improved the paper.

\section{LITERATURE CITED}

Aeby G (2002) Trade-offs for the butterflyfish, Chaetodon multicinctus, when feeding on coral prey infected with trematode metacercariae. Behav Ecol Sociobiol 52: 158-165

Ainsworth TD, Kvennefors EC, Blackall L, Fine M, HoeghGuldberg O (2007) Disease and cell death in white syndrome of acroporid corals on the Great Barrier Reef. Mar Biol 151:19-29

Allemand D, Tambutté E, Zoccola E, Tambutté S (2011) Coral calcification, cells to reefs. In: Dubinsky Z, Stambler $\mathrm{N}$ (eds) Coral reefs: an ecosystem in transition. Springer, Berlin, p 119-150

Antonius A, Riegl B (1997) A possible link between coral diseases and a corallivorous snail (Drupella cornus) outbreak in the Red Sea. Atoll Res Bull 447:1-9
Bentis CJ, Kaufman L, Golubic S (2000) Endolithic fungi in reef-building corals (Order: Scleractinia) are common, cosmopolitan, and potentially pathogenic. Biol Bull (Woods Hole) 198:254-260

> Bourne D, Ainsworth T, Pollock F, Willis B (2015) Towards a better understanding of white syndromes and their causes on Indo-Pacific coral reefs. Coral Reefs 34: 233-242

Brawley SH, Adey WH (1982) Coralliophila abbreviata: a significant corallivore! Bull Mar Sci 32:595-599

Chen MH, Soong K, Tsai ML (2004) Host effect on size structure and timing of sex change in the coral-inhabiting snail Coralliophila violacea. Mar Biol 144:287-293

Cole AJ, Chong Seng KM, Pratchett MS, Jones GP (2009) Coral-feeding fishes slow progression of black-band disease. Coral Reefs 28:965

$>$ De'ath G, Fabricius K, Sweatman H, Puotinen M (2012) The 27-year decline of coral cover on the Great Barrier Reef and its causes. Proc Natl Acad Sci USA 109:17995-17999

$>$ Fine M, Roff G, Ainsworth TD, Hoegh-Guldberg O (2006) Phototrophic microendoliths bloom during coral 'white syndrome'. Coral Reefs 25:577-581

Lozada-Misa P, Kerr A, Raymundo L (2015) Contrasting lesion dynamics of white syndrome among the scleractinian corals Porites spp. PLoS One 10:e0129841

Mass T, Drake JL, Peters EC, Jiang WG, Falkowski PG (2014) Immunolocalization of skeletal matrix proteins in tissue and mineral of the coral Stylophora pistillata. Proc Natl Acad Sci USA 111:12728-12733

McIlwain JL, Jones GP (1997) Prey selection by an obligate coral-feeding wrasse and its response to small-scale disturbance. Mar Ecol Prog Ser 155:189-198

Moyer JT, Emerson WK, Ross M (1982) Massive destruction of scleractinian corals by the muricid gatropod, Drupella, in Japan and the Philippines. Nautilus 96:69-82

Myers RL, Raymundo LJ (2009) Coral disease in Micronesian reefs: a link between disease prevalence and host abundance. Dis Aquat Org 87:97-104

Nicolet K, Hoogenboom MO, Gardiner NM, Pratchett MS, Willis BL (2013) The corallivorous invertebrate Drupella aids in transmission of brown band disease on the Great Barrier Reef. Coral Reefs 32:585-595

> Nugues MM, Bak RPM (2009) Brown-band syndrome on feeding scars of the crown-of-thorn starfish Acanthaster planci. Coral Reefs 28:507-510

> Nugues MM, Smith GW, van Hooidonk RJ, Seabra MI, Bak RPM (2004) Algal contact as a trigger for coral disease. Ecol Lett 7:919-923

> Oren U, Brickner I, Loya Y (1998) Prudent sessile feeding by the corallivore snail Coralliophila violacea on coral energy sinks. Proc R Soc Lond B Biol Sci 265: 2043-2050

> Page CA, Willis BL (2008) Epidemiology of skeletal eroding band on the Great Barrier Reef and the role of injury in the initiation of this widespread coral disease. Coral Reefs 27:257-272

Palmer CV, Mydlarz LD, Willis BL (2008) Evidence of an inflammatory-like response in non-normally pigmented tissues of two scleractinian corals. Proc R Soc Lond B Biol Sci 275:2687-2693

> Pollock FJ, Katz SM, Bourne DG, Willis BL (2013) Cymo melanodactylus crabs slow progression of white syndrome lesions on corals. Coral Reefs 32:43-48

Raymundo LJ, Halford AR, Maypa AP, Kerr AM (2009) Functionally diverse reef-fish communities ameliorate 
coral disease. Proc Natl Acad Sci USA 106:17067-17070

Sato Y, Willis BL, Bourne DG (2010) Successional changes in bacterial communities during the development of black band disease on the reef coral, Montipora hispida. ISME J 4:203-214

Sudek M, Work TM, Aeby GS, Davy SK (2012) Histological observations in the Hawaiian reef coral, Porites compressa, affected by Porites bleaching with tissue loss. J Invertebr Pathol 111:121-125

Sussman M, Loya Y, Fine M, Rosenberg E (2003) The marine fireworm Hermodice carunculata is a winter reservoir and spring-summer vector for the coral-bleaching pathogen Vibrio shiloi. Environ Microbiol 5:250-255

Tribollet A (2008) The boring microflora in modern coral reef ecosystems: a review of its roles. In: Wisshak M, Tapanila L (eds) Current developments in bioerosion. Springer, Berlin

Ward J (1965) The digestive tract and its relation to feeding habits in the stenoglossan prosobranch Coralliophila abbreviata (Lamark). Can J Zool 43:447-464

Williams DE, Miller MW (2005) Coral disease outbreak: pat-

Editorial responsibility: Garriet Smith,

Aiken, South Carolina, USA tern, prevalence and transmission in Acropora cervicornis. Mar Ecol Prog Ser 301:119-128

Williams GJ, Work TM, Aeby GS, Knapp IS, Davy SK (2011) Gross and microscopic morphology of lesions in Cnidaria from Palmyra Atoll, Central Pacific. J Invertebr Pathol 106:165-173

- Work TM, Aeby GS (2014) Microbial aggregates within tissues infect a diversity of corals throughout the IndoPacific. Mar Ecol Prog Ser 500:1-9

Work T, Meteyer C (2014) To understand coral disease, look at coral cells. EcoHealth 11:610-618

> Work TM, Russell R, Aeby GS (2012) Tissue loss (white syndrome) in the coral Montipora capitata is a dynamic disease with multiple host responses and potential causes. Proc R Soc Lond B Biol Sci 279:4334-4341

Work TM, Aeby GS, Lasne G, Tribollet A (2014) Gross and microscopic pathology of hard and soft corals in New Caledonia. J Invertebr Pathol 120:50-58

Work TM, Aeby GS, Hughen K (2016) Gross and microscopic lesions in corals from Micronesia. Vet Pathol 53: 153-162

Submitted: October 5, 2015; Accepted: February 18, 2016

Proofs received from author(s): March 22, 2016 